\title{
The Cycle of Fear in Learning: The Case for Foreign Language
}

Derwina Daud, Chong Peng Hwa, Zeng Jincheng, Haryati Ahmad, Aminabibi Satanihpy @ Saidalvi, Noor Hanim Rahmat

To Link this Article: http://dx.doi.org/10.6007/IJARBSS/v11-i11/11618

DOI:10.6007/IJARBSS/v11-i11/11618

Received: 11 September 2021, Revised: 13 October 2021, Accepted: 28 October 2021

Published Online: 14 November 2021

In-Text Citation: (Daud et al., 2021)

To Cite this Article: Daud, D., Hwa, C. P., Jincheng, Z., Ahmad, H., Saidalvi, A. S. @, \& Rahmat, N. H. (2021). The Cycle of Fear in Learning: The Case for Foreign Language. International Journal of Academic Research in Business and Social Sciences, 11(11), 1433 - 1446.

Copyright: (c) 2021 The Author(s)

Published by Human Resource Management Academic Research Society (www.hrmars.com)

This article is published under the Creative Commons Attribution (CC BY 4.0) license. Anyone may reproduce, distribute, translate and create derivative works of this article (for both commercial and non0-commercial purposes), subject to full attribution to the original publication and authors. The full terms of this license may be seen

at: http://creativecommons.org/licences/by/4.0/legalcode

Vol. 11, No. 11, 2021, Pg. 1433 - 1446

Full Terms \& Conditions of access and use can be found at http://hrmars.com/index.php/pages/detail/publication-ethics 


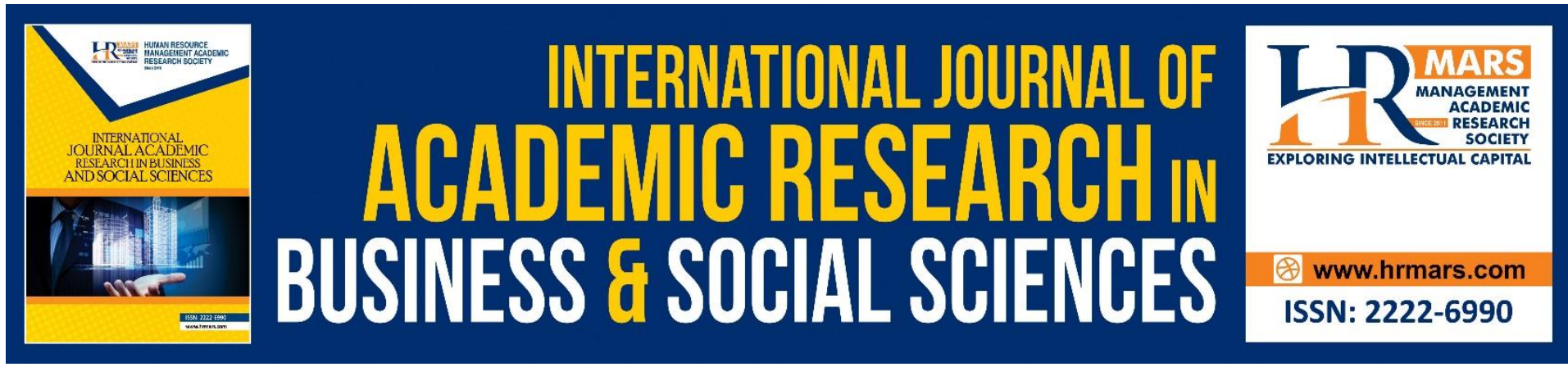

\title{
The Cycle of Fear in Learning: The Case for Foreign Language
}

\author{
Derwina Daud ${ }^{1}$, Chong Peng Hwa², Zeng Jincheng ${ }^{3}$, Haryati \\ Ahmad ${ }^{4}$, PM Dr Aminabibi Satanihpy @ Saidalvi ${ }^{5}$, Noor Hanim \\ Rahmat $^{6}$ \\ ${ }^{1,4}$ Akademi Pengajian Bahasa, Universiti Teknologi MARA Cawangan Johor, Kampus \\ Segamat, ${ }^{3}$ Foreign Language Studies, Hunan University of Humanities, Science \& \\ Technology, 2,5,6Akademi Pengajian Bahasa, Universiti Teknologi MARA Cawangan Johor, \\ Kampus Pasir Gudang \\ Email: derwi293@uitm.edu.my, chong900@uitm.edu.my, zjcamy@126.com, \\ harya395@uitm.edu.my, aminabibi@uitm.edu.my, noorh763@uitm.edu.my
}

\begin{abstract}
The year of 2020 has marked the large-scale movement of online activities all around the globe. Due to COVID-19, almost all educational institutions were temporarily closed down and teaching had to be conducted online. One of the critical subjects that also had been affected by this pandemic is the teaching and learning of foreign language. This quantitative study aimed at exploring participants' perceptions of learning foreign language and also how negative emotions influenced their learning. Questionnaires for this study were adapted from Horwitz, Horwitz and Cope (1986). Questionnaire data were collected from 71 undergraduates from a public university in Malaysia ranged from Semester 1 until 5. The means range between 2.8 to 3.3. The analysis suggest that students are very much influenced with fear of foreign language learning and this has caused them not to excel. Findings from this study would assist future research in seeking learners' preferences in enhancing their engagement in online foreign language learning.
\end{abstract}

Keywords: Foreign Language, Online Learning, Readiness, Perceptions.

\section{Introduction}

\section{Background of Study}

According to Moeller \& Catalano (2015), foreign language is a language that is taught in classroom setting. In particular, foreign language refers to languages that are learned and taught as part of a requirement for certain courses. Studying foreign language allows learners to participate creatively in real life situations and at the same time provide vast opportunities to gain linguistic and social knowledge.

Foreign language has proven to cause lower confidence among learners. Findings from Abdullah \& Daud (2017) suggested that foreign language learners had to deal with a low selfassertiveness in learning Arabic as their foreign language. The respondents of this were 
chosen from among 30 students in the third semester of the Business Communication programme. They were chosen because, at the time the study was done, they were enrolled in UiTM Johor's third (highest) level Arabic language course. Analysis from this study has concluded that with the help of right techniques of presentations from lecturers, learners will eventually be able to overcome their metacognitive skills.

In relation to the FLL landscape in Malaysia, the onset of e-learning began in the 1990s when the Higher Learning Institutions introduced it as part of teaching and learning methods. The pandemic that took place in 2020 has triggered the acceleration of online learning, and since then, those involved in teaching are obliged to deliver classes online.

Ismail et. al (2021) conducted a study on seeking learners' readiness on online learning, specifically in foreign language. The study employed students from local universities; UNIKL and IIUM who took up foreign languages. The analysis indicated that mostly respondents display high confidence in online FLL, as they are well-exposed to the technology and needed tools.

A study that assessed learners' level of communication anxiety was carried out by Hassani and Rajab (2012) concluded that learners with less proficiency possess high level of anxiety as compared to those with high proficiency. The study employed a group of Iranian students of Intensive English Program in UTM, Malaysia. The study further deduced that language anxiety stems from poor language learning ability.

\section{Statement of Problem}

The COVID-19 pandemic has caused a shift in education from physical classrooms to digital platforms, which has resulted in a slew of issues, including not just technical but also psychological issues among students (Arribathi et al., 2021). Amid a pandemic, students experience worries about a variety of anxiety types during the learning process. The fear of foreign language learning is more acute in such critical learning situations. Because of the online platforms, which limit face-to-face interactions and influence the foreign language learning process, teachers and students encounter challenges (O'Doherty et al., 2018). Increased anxiety among language learners in online sessions may have a negative impact on their performance and achievement. During the learning process, anxiety influences a person's emotions, cognition, and behaviour.

Students might become more communicatively apprehensive as a result of internal feelings of discomfort caused by negative evaluation in the learning process and/or previous adversely communicate encounters with others. Individuals can disclose the influence of their anxiety of learning a foreign language by self-awareness of communication apprehension as reflected in their thoughts and feelings. Understanding the factors of foreign language anxiety will assist to identify solutions to the problem of foreign language learning (Naser Oteir \& Nijr Al-Otaibi, 2019). Hence, this study is done to investigate how online learning influences engagement.

\section{Objective and Research Questions}

Generally, this study explores the cycle of fear in learning foreign languages. This study is done to answer the following questions; 
1.1.1 How does communication apprehension influence fear of foreign language learning?

1.1.2 How does negative evaluation influence fear of foreign language learning?

1.1.3 How does test anxiety influence fear of foreign language learning?

\section{Literature Review}

\section{Introduction}

This section presents the theories related to self-fulling prophecy, fear of language learning, past studies in foreign language learning and also the conceptual framework of the study.

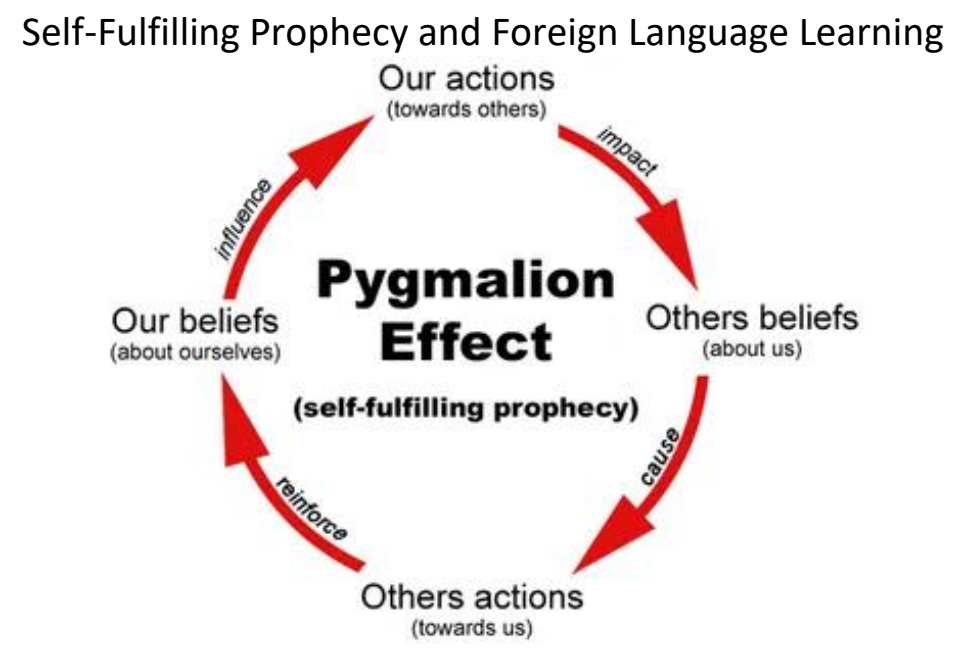

Figure 1-Self-Fulfilling Prophecy

(Source: Merton, 1948)

Figure 1 above presents the classic view of self-fulfilling prophecy by Merton (1948). This prophecy is a phenomenon of someone predicting something. This prediction becomes true because the person believes it is tur. The person's behaviour aligns to fulfil this prediction.

\section{Fear of Foreign Language Learning}

Fear of foreign language learning is common among many learners. Past researches shown that learners had communication apprehension when it comes to foreign language(Naudhani et al., 2018). They fear tests, making mistakes, and negative evaluation(Sadighi \& Dastpak, 2017). Language anxiety can be subdivided into three categories: trait anxiety, state anxiety and situation-specific anxiety(Horwitz, 2001). Trait anxiety is a personality- related stable characteristic, while state anxiety is stimulated by a temporary state. State anxiety can change over time or fluctuate depending on situations(Rahmat, 2020). Situation-specific anxiety is aroused by a specific type of situation or event(Král'ová \& Sorádová, 2015). It occurs only when the language learners are experiencing an unfavourable condition(Rahmat, 2020). Three main factors are considered as the causes of fear, namely, the learners themselves, the task and the teaching-learning environment(Rahmat, 2019).

\section{Past Studies}

This section discusses issues related to foreign language learning, fear of foreign language learning, learning language online, and also the conceptual framework of the study. 


\section{Past Studies on Foreign Language Learning}

Many studies have been carried out to investigate the learning of foreign languages. These include motivation in learning foreign language (Redzuan, 2021; ALKaab, 2021), foreign language learning strategies (Ahmad, Yunus \& Hasan, 2016; Malik \& Asnur, 2019), and foreign language learning process (Biletska et. al., 2021)

In addition, there have been many past studies on communication apprehension in foreign language learning. Wan Mustapha et. al (2010) studied the communication apprehension of 50 final year Business Administration students at a Malaysian public university. Using Personal Report of Communication Apprehension (PRCA-24) as their research instrument, they found that $45 \%$ of the students exhibited high level of communication apprehension, while $26 \%$ and $29 \%$ of them exhibited average and low levels of communication apprehension respectively. Public speaking was found as the communication context most feared by the students. The study by Jalleh, Mahfoodh, and Singh (2021), on the other hand, investigated the oral communication apprehension of 23 Japanese EFL students in an immersion programme in a Malaysian public university. PRCA-24 was utilised to measure the students' oral communication apprehension levels and the findings revealed that these students had high levels of oral communication apprehension especially regarding group discussion and conversation. It was concluded that the Japanese EFL students were facing highest level of oral communication apprehension in these two communication contexts because of the spontaneity required when discussing and conversing with others.

Manipuspika (2018) used Foreign Language Classroom Anxiety Scale (FLCAS) and Likert-type Willingness to Communicate (WTC) Scale to study the correlation between anxiety and willingness to communicate in 98 respondents from an English department in an Indonesian university. The study also examined the students' anxiety level and the types of anxiety experienced by them. The study discovered that there was a strong positive correlation between the Indonesian EFL learners' anxiety and willingness to communicate. Other than that, it was also discovered that learners had high level of anxiety that contributed to their low desire to speak in the target language. The study also revealed that the types of anxiety faced by the learners are communication apprehension, fear of negative evaluation, and test anxiety.

\section{Past studies on Fear of Foreign Language Learning (FLL)}

Studies have shown that students learning a foreign language face the fear of being judged negatively. The fear of negative evaluation refers to apprehension about the opinions of others ((Horwitz et al., 1986). Rafek et al (2018), investigated 56 university students' perceptions of negative evaluation and the level of anxiety for different genders using a set of questionnaires adapted from FLCAS (Foreign Language Class Anxiety Scale) by Horwitz (1983). They discovered that students were anxious for receiving evaluations from both lecturers and peers. A more recent sequential-mixed method study of 11 interviewees and 33 questionnaire respondents by James, Amini \& Yaqubi (2020) reported that students were slightly anxious when given negative evaluation. Furthermore, foreign language anxiety can rise to other types of anxiety, which can negatively impact students' academic performance. This was highlighted by Baharuddin and Rashid (2014), in an investigation of 70 undergraduate ESL students of Universiti Putra Malaysia (UPM. The findings revealed that fear of negative evaluation was linked to communication anxiety among 70 undergraduate 
ESL students of Universiti Putra Malaysia (UPM). Students' communication was hampered by their fear of evaluation or being judged.

Besides, students also feel embarrassed when negatively evaluated. For example, in research comparing Malaysian and Chinese students, Zulkifli (2007) found that when students were corrected by their language teacher, Malaysian students were more embarrassed than Chinese students. Similarly, Wang (2005) studied the positive and negative perceptions of evaluation among EFL university students in Mainland China came to the same conclusion. More than half of the participants in China stated that they felt highly self-conscious while speaking in English because they were afraid of being laughed at by their classmates. However, it was highlighted in the same study that these students valued the corrective feedback given by the English teacher.

Another important aspect to consider when being negatively evaluated is the feeling of uneasiness among students and the influence of particular culture. Students at the University of Sargodha who enrolled in English speaking, reading, and listening programmes reported feeling anxious when forced to interact in English. They were less concerned about understanding other speakers but highly worried about making mistakes in English (Awan, Azher, Anwar, \& Naz, 2010). A comprehensive study by Soo and Goh (2013) concluded that the reason for Asian students to be more passive in the teaching-learning process is due to the nature of Asian cultures since they value "face" and avoided situations that could jeopardise it. So, students believed that they would "lose their face" if peers and language teachers realised their ability in the language.

\section{Past Studies on Learning Foreign Language Online}

The pandemic has witnessed the rise of various research areas that focus on online learning. In one of the most recent studies, Talal (2021) conducted a research on online foreign language specifically English and found that online learning offers flexibility and borderless education. As for the effectiveness, it provides comfort to the students as assessments and evaluations are carried out based on grades, not built on opinions of lecturers. There were 20 respondents from different colleges from The World Islamic Sciences \& University, Amman, Jordan who were interviewed and were found that online learning allows learners to retain information longer. This is done with the help of the repeated watching and revising materials shared online.

As mentioned by Azelain (2020), the use of short videos in classes, in particular flipped classroom has shed positive effects to the students. As videos allow students to the great exposure of new content outside the class, learners will be able to learn topics in their own time at their own convenience. Her research was carried out with 174 participants 


\section{Conceptual Framework}

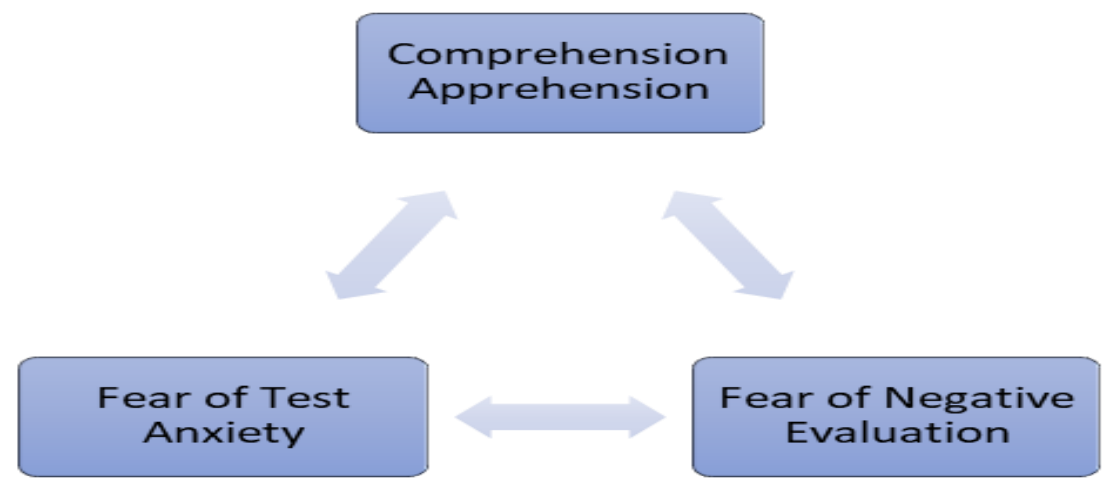

Figure 2- Conceptual Framework of the Study

(Source : Horwitz, Horwitz and Cope,1986)

The conceptual framework of the study is presented in figure 2 below. This study is scaffolded on the theory of self-fulfilling prophecy. Fear in foreign language is seen as a cycle. Horwitz, Horwitz and Cope (1986) list three types of foreign language fear. Learners begin with comprehension apprehension and this refers to the learner not feeling sure when they spoke the foreign language in the class. They may get nervous and confused when asked to speak the target language (foreign language). This fear gives impact on the learners' perception of evaluation. This fear of negative evaluation then makes the learner fear to take test in foreign learning.

\section{Methodlogy}

This quantitative study is done to investigate the fear of foreign language learning. 71 participants were purposely chosen from a public university in Malaysia. They registered for a variety of foreign language courses the previous semester. The instrument (refer to table 1). used is a survey adapted from Horwitz, Horwitz and Cope (1986). Apart from the demographic profile in Section A., there are 3 other sections. Section B has 11 items on Comprehension apprehension, section $D$ has 7 items on fear of negative evaluation, section D has 15 items on test anxiety.

Table 1-Distribution of Items in Instrument

\begin{tabular}{|l|l|l|}
\hline SECTION & CONSTRUCTS & NO OF ITEMS \\
\hline B & COMMUNICATION APPREHENSION & 11 \\
\hline C & FEAR OF NEGATIVE EVALUATION & 7 \\
\hline D & TEST ANXIETY & 15 \\
\hline & & 33 \\
\hline
\end{tabular}

Table 2- Reliability Statistics

\section{Reliability Statistics}

\begin{tabular}{r|r}
$\begin{array}{c}\text { Cronbach's } \\
\text { Alpha }\end{array}$ & N of Items \\
\hline .860 & 33 \\
\hline
\end{tabular}


Data is collected via goggle form and analysed using SPSS version 26 . With reference to table 2 , the SPSS analysis revealed a Cronbach analysis of . 860 thus showing high internal reliability for the instrument. Data is presented in terms of percentage for the demographic profile and mean scores to answer the research questions.

\section{Findings}

\section{Introduction}

This section presents the findings of this study. The findings are presented to answer the research questions above.

Findings for Demographic Profile

\section{Q1.Gender}

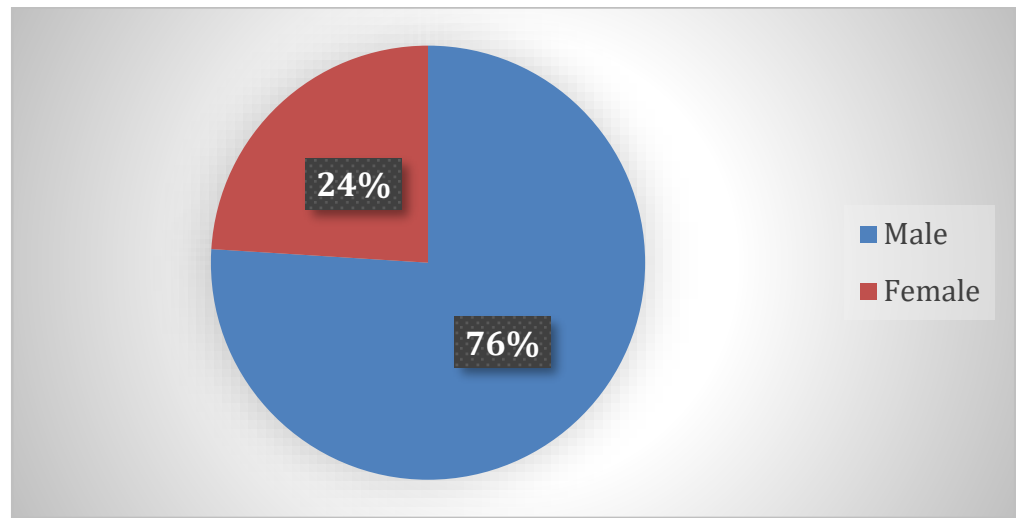

Figure 3- Percentage for Gender

Participants for the study were taken from students who were required to take foreign language classes as a subject study in university. In this study, there were a total of 71 respondents who completed the questionnaire. Figure 3 demonstrates that the majority of the respondents (76\%) were male students, while only 24 percent were female students.

\section{Q2 Semester}

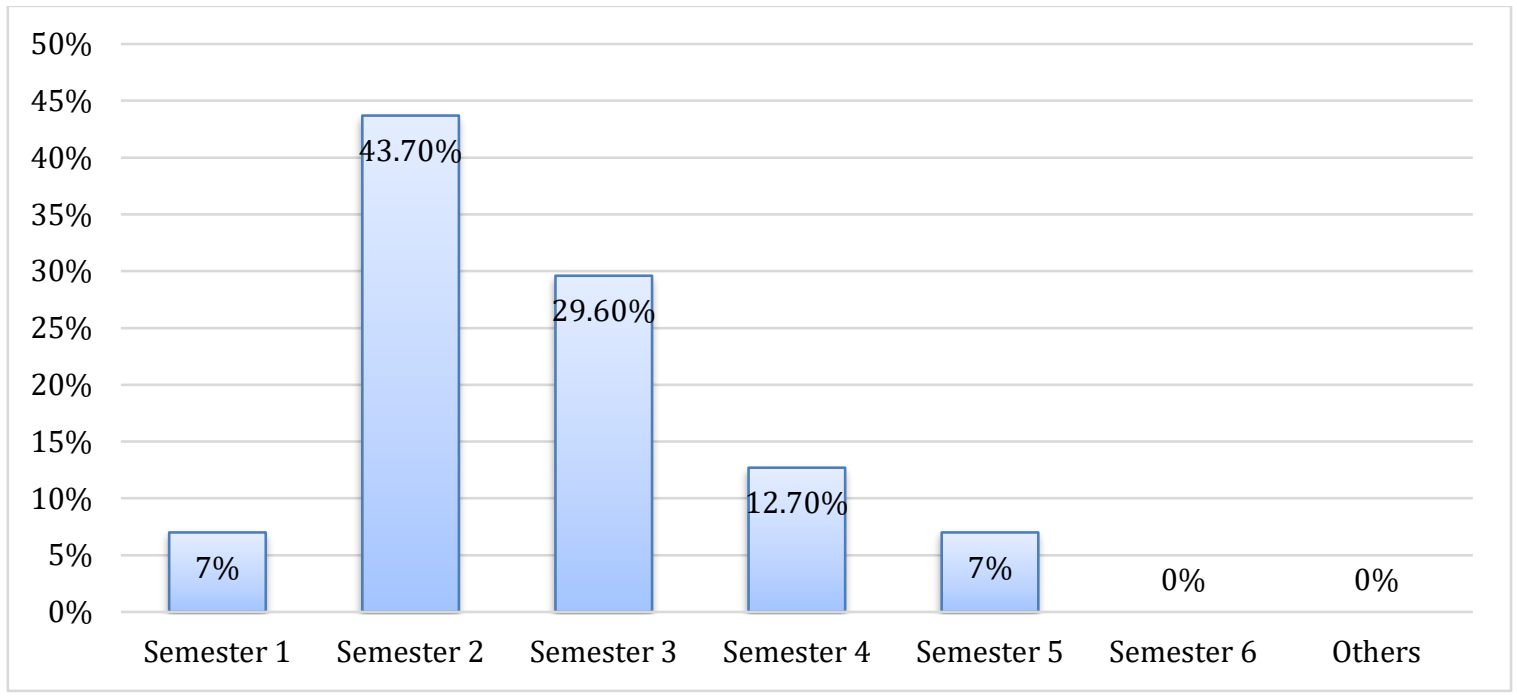

Figure 4-Percentage for Semester 
Figure 4 shows responses to a questionnaire about fear of learning a foreign language by 5 semesters of university students. According to the statistics, 43.7 percent of those who responded were semester 2 students. In their online classes, $29.6 \%$ of the total responses from semester 3 answered a question about foreign language acquisition. Students in semester 4 made up about 9 students, or $12.7 \%$ of the total participants, who actively participated in the online survey. Students in the first and fifth semesters had the same proportion of the sample (7\%) who said that they were fearful of learning a foreign language.

\section{Findings for Communication Apprehension}

This section presents findings to answer research question number 1: How does communication apprehension influence fear of foreign language learning?

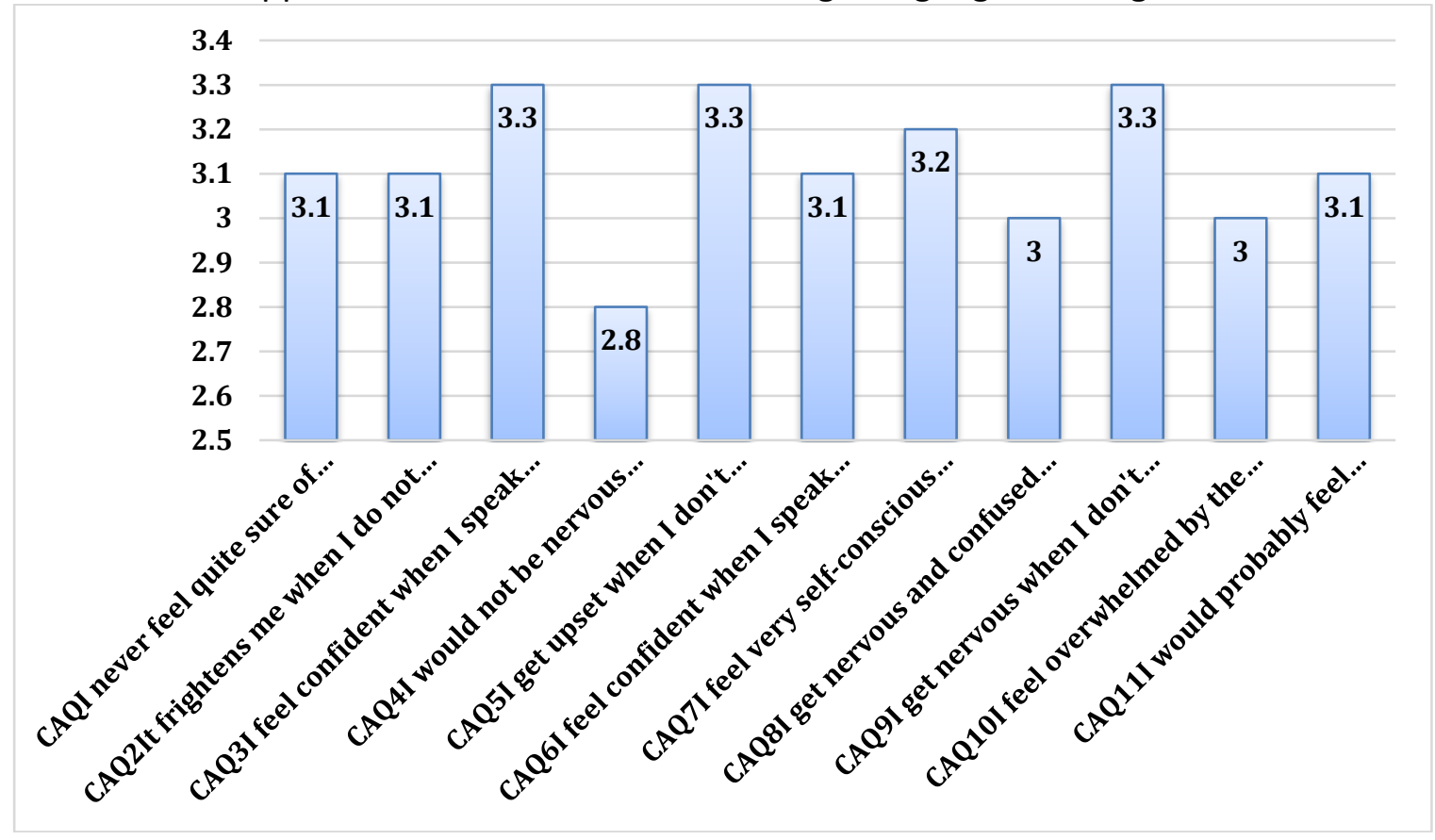

Figure 5- mean for Communication Apprehension

The findings in the above figure explored that communication apprehension influence fear of foreign language learning. Foreign language learners suffered when they don't understand what the teacher says or is correcting in a foreign language class (mean=3.1). They feel very self-conscious about speaking the foreign language in front of other students (mean= 3.2 ) and are overwhelmed by the number of rules they have to learn to speak a foreign language (mean=3). They tend to feel comfortable around native speakers of the foreign language. It is clear from the result that teachers can be a cause of anxiety, which is in accordance with past researches(Naudhani et al., 2018). It should be the teacher's work to help the learners to have positive attitudes towards correcting, giving them more encouragement for foreign language practice. 


\section{Findings for Fear of Negative Evaluation}

This section presents the answer to research question 2: How does negative evaluation influence fear of foreign language learning?

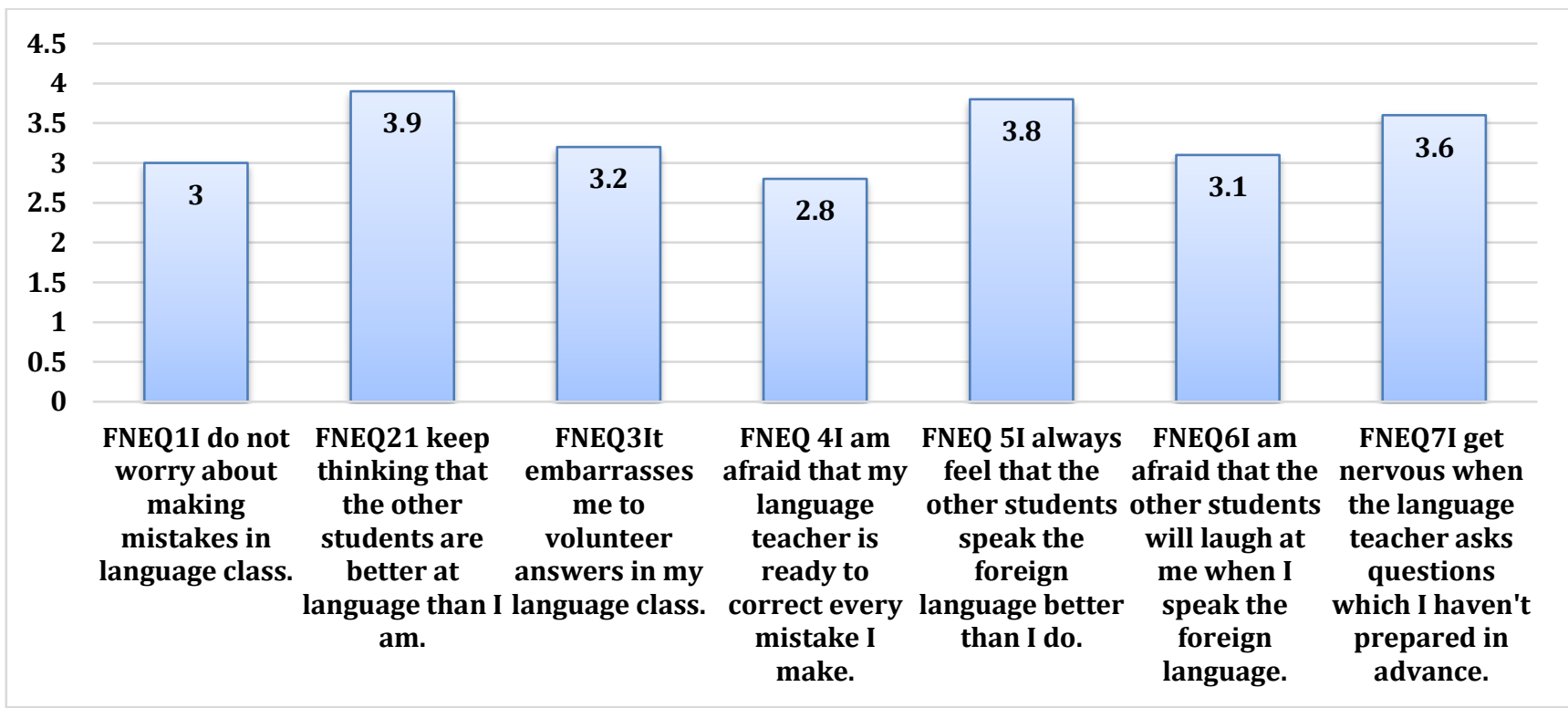

Figure 6- Mean for Fear of Negative Evaluation

Figure 6 summarised the mean for fear of negative evaluation. The findings show that the respondents "keep thinking that the other students are better at language" (3.9) and "always feel that the other students speak the foreign language better" (3.8). It was also revealed that the respondents "get nervous when the language teacher asks questions" which they have not prepared for in advance (3.6).

\section{Findings for Test Anxiety}

This section presents data to answer research question 3: How does test anxiety influence fear of foreign language learning?

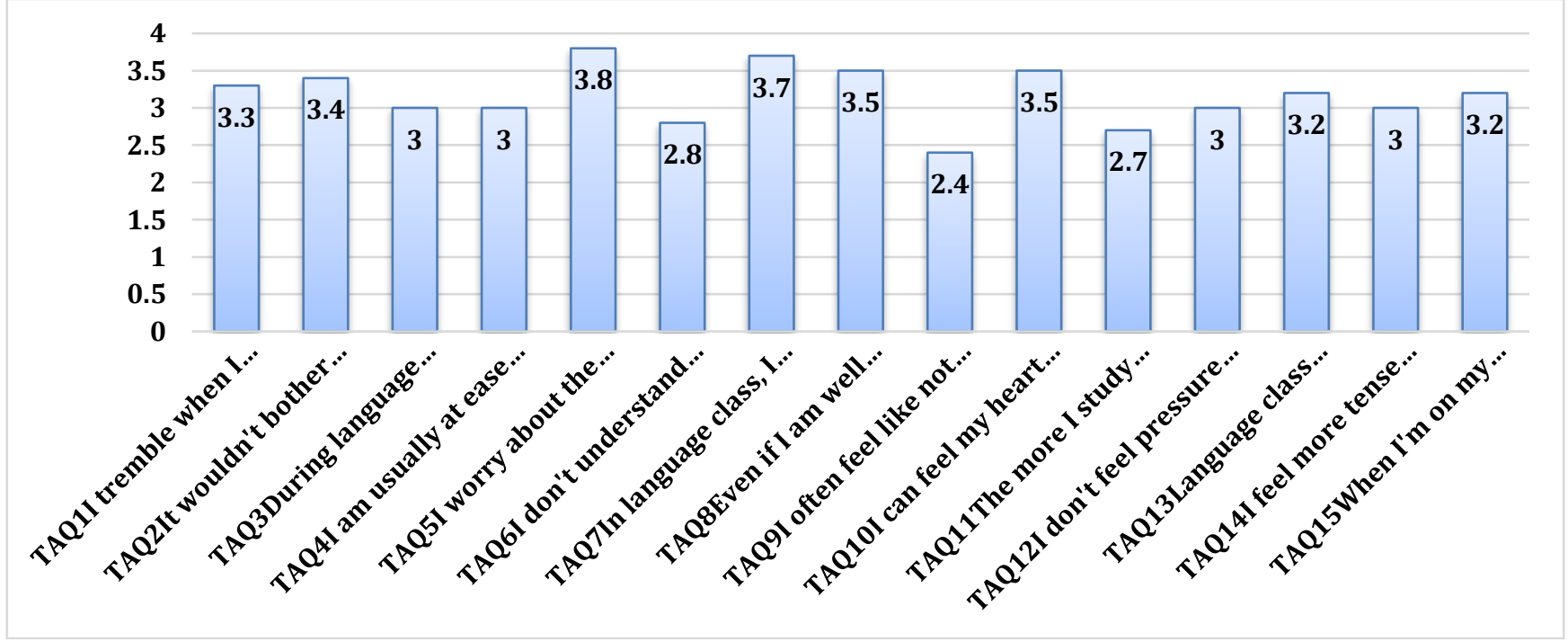

Figure 7-Mean for Test Anxiety 
Based on Figure 7, the mean for test anxiety findings reveals that the respondents in their foreign language class " worry about the consequences of failing " (3.8). Furthermore, individuals " can get so nervous " (3.7) that they forget things they know. Respondents also stated that they " feel anxious in language class " (3.5) even though they are well prepared and that their "heart-pounding" occurs when they are called during class.

\section{Conclusion}

\section{Summary of Findings and Discussion}

This study was done to explore how communication apprehension, negative evaluation, test anxiety influence the learning of foreign language. Data analysed revealed interesting findings. Ironically, communication apprehension caused by teacher. Foreign language learners were apprehensive about their communication when they were not sure of the answers to the questions that the teachers asked. They were also self-conscious of how they appeared in class. This is also agreed by Naudhani et al., 2018 who said that teachers caused the anxiety.

Next, learners had low self-esteem. They were made to believe that other students were better than them. Coincidently, this snowballs into them being why they (the learners) were nervous when the teacher asks questions- fear negative evaluations. Finally, learners worried about the consequences of failing, even when they are prepared for the text. Findings from this study revealed that foreign language learners are apprehensive about communicating with native speakers or their peers in the target language. Communicating in a language foreign can often cause learners to be apprehensive. The study by Wan Mustapha et. al (2010); Jalleh, Mahfoodh, \& Singh (2021) also revealed that foreign language learners fear communication in the target language because they had to be spontaneous. Consequently, Manipuspika (2018) also felt that foreign language learners had high level of anxiety that contributed to their low desire to speak in the target language. In addition to that, this study also showed that foreign language learners are often worried that the were not as good as their peers. The study by Zulkifli (2007) also reported that foreign language learners feared being laughed at. Rafek et al (2018) also found that this fear of negative evaluation negatively impact students' academic performance.

\section{Pedagogical Implications and Suggestions for Future Research}

Findings in this study has shown interesting discoveries on what made learners fear foreign language learning; they fear (a) the foreign language teachers and (b) the classroom atmosphere. It is suggested that foreign language teachers need to set the mode for a conducive foreign language learning environment-be it face-to-face or online. In addition to that, foreign language teachers need to gear their teaching style to suit the needs of the learners who needed their self-esteem to be lifted in order to benefit most from the foreign language classes.

Talal (2021) suggested that teachers can assist in the de-emergence of social isolation among learners by building rapport through small talks. Class sizes is also one of the indispensable elements in crafting enjoyment among the foreign language learners. As for intermediate and low achievers, getting additional attention from teachers would help them to break the barrier of achieving the objective of online FL learning (Maican \& Cocoradă, 2021) 


\section{Suggestions for Future Research}

Findings from this research has helped researchers to see students' readiness in online FLL. However, for future research, students' preference in terms of skills to be taught online should be looked at. Analysis from this future research would assist instructors, policy makers to determine which skill can be delivered successfully, while the least favoured skills can be taught face-to-face. This is in relation to the blended learning method as suggested by (Maican \& Cocorada, 2021).

Another area that is worth investigating in relation to online engagement among learners, research on technical supports could also assist those involved in finding out their level of engagement. As mentioned by Ismail, Saaludin, Mohd Ali \& Zainal Abidin (2021), students are well-prepared in facing online learning, as they possess high level of confidence in computer.

\section{References}

Abdullah, M. R., \& Daud, D. B. (2017). Communication Apprehension among Non- Native Speakers of Arabic in UiTM Johor. May 2016, 0-17. Proceeding for International Jasin Multimedia \& Computer Science Invention and Innovation Exhibition. Retrieved from https://ir.uitm.edu.my/id/eprint/50410/1/50410.pdf

Ahmad, H., Yunus, M. M., \& Hasan N. H. (2016). English vocabulary size and vocabulary learning strategies of UiTM pre-diploma students. $4^{\text {th }}$ International Conference on Language, Education, Humanities and Innovation, 16 \& 17 September, 150-170. Retrieved from https://icsai.org/procarch/4iclehi/4iclehi-064.pdf

ALKaab, S. N. S. (2021). Motivation to learn English as a foreign language among Iraqi students. Review of International Geographical Education (RIGEO), 11(5), 3471-3478. Retrieved from https://doi.org/10.48047/rigeo.11.05.235

Arribathi, A. H., Suwarto, Miftakhu Rosyad, A., Budiarto, M., Supriyanti, D., \& Mulyati. (2021). An Analysis of Student Learning Anxiety During the COVID-19 Pandemic: A Study in Higher Education. The Journal of Continuing Higher Education, 1-14. https://doi.org/10.1080/07377363.2020.1847971

Azelain, C. D. (2016). Students' Engagement in Online Language Learning Through Short Video Lessons. Porta Linguarum Revista Interuniversitaria de Didáctica de Las Lenguas Extranjeras. Published. https://doi.org/10.30827/digibug.53943

Azher, M., Anwar, M. N., \& Naz, A. (2010). An investigation of foreign language classroom anxiety and its relationship with students achievement. Journal of College Teaching \& Learning (TLC), 7(11). Retrieved from https://doi.org/10.19030/tlc.v7i11.249

Baharuddin, S. S., \& Rashid, S. M. (2014). English language learning anxiety and oral performance among undergraduate ESL learners.Journal of Language and Communication, 1(2), 137-154. Retrieved from https://fbmk.upm.edu.my/dokumen/FKBMK1_JLC_1(2)_2014_(2).pdf\#page=37

Biletska, I. O, Paladieva, A. F., Avchinnikova, H. D. \& Kazak, Y. Y. (2021). The use of modern technologies by foreign language teachers: developing digital skills. Linguistics and Culture Review, 5(25), 16-27. Retrieved from https://doi.org/10.37028/lingcure.v5nS2.1327

Hassani, S., \& Rajab, A. (2012). General Communication Anxiety among EFL Students; A Case of Iranian Students of Intensive English Programs. Procedia - Social and Behavioral Sciences, 66, 410-418. https://doi.org/10.1016/j.sbspro.2012.11.284 
Horwitz, E. K., Horwitz, M. B., \& Cope J. A. (1986). Foreign language classroom anxiety. Modern Language Journal, 70, 125-132. Retrieved from http://dx.doi.org/10.1111/j.1540-4781.1986.tb05256.x

Ismail, M. H., Saaludin, N., Haji Mohd Ali, S. N. D., \& Zainal Abidin, I. S. (2021). The Foreign Language Students' Readiness on Online Learning in Malaysia (Vol. 8, Issue 2). Readers Insight Publisher. https://doi.org/10.31580/apss.v8i2.1909

Jalleh, C. M., Mahfoodh, O. H. A., \& Singh, M. K. M. (2021). Oral communication apprehension among Japanese EFL international students in a language immersion program in Malaysia. International Journal of Instruction, 14(2), 155-178. Retrieved from https://doi.org/10.29333/iji.2021.14210a

Král'ová, Z., \& Sorádová, D. (2015). Foreign language learning anxiety. Teaching Foreign Languages to Learners with Special Educational Needs, 1, 7-28. Retrieved from http://dx.doi.org/10.17846/SEN.2015.91-100

Maican, M. A., \& Cocoradă, E. (2021). Online Foreign Language Learning in Higher Education and Its Correlates during the COVID-19 Pandemic. Sustainability, 13(2), 781. https://doi.org/10.3390/su13020781

Malik, A. R., \& Asnur, M. N. A. (2019). Using social media as a learning media of foreign language students in higher education. Bahtera: Jurnal Pendidikan Bahasa Dan Sastra, 18(2), 166-175. https://doi.org/10.21009/BAHTERA.182.06

Manipuspika, Y. S. (2018). Correlation between anxiety and willingness to communicate in the Indonesian EFL context. Arab World English Journal (AWEJ), 9(2), 200-217. Retrieved from https://dx.doi.org/10.24093/awej/vol9no2.14

Merton, R. K. (1948). The self-fulfilling prophecy. The Antioch Review, 8(2), 193-210. Retrieved from http://www.jstor.org/stable/4609267?origin=JSTOR-pdf

Moeller, A. J., \& Catalano, T. (2015). Foreign Language Teaching and Learning. International Encyclopedia of the Social \& Behavioral Sciences, 327-332. https://doi.org/10.1016/b978-0-08-097086-8.92082-8

Naudhani, M., Wu, Z., \& Naudhani, S. (2018). Exploring the factors of foreign language anxiety among Chinese undergraduate English majors and Non-English majors. International Journal of English Linguistics, 8(5), 142-150. Retrieved from https://www.ccsenet.org/ journal/index.php/ijel/article/view/75871

O’Doherty, D., Dromey, M., Lougheed, J., Hannigan, A., Last, J., \& McGrath, D. (2018). Barriers and solutions to online learning in medical education - an integrative review. $B M C$ Medical Education, 18(1). https://doi.org/10.1186/s12909-018-1240-0

Rahmat, N. H. (2019). Cycle of fear in learning: The case for three language skills. American Journal of Social Sciences and Humanities, 4(1), 151-162. Retrieved from https://onlinesciencepublishing.com/index.php/ajssh/article/view/129

Rahmat, N. H. (2020). Investigating the cycle of fear in foreign language learning. European Journal of Foreign Language Teaching, 5(1). Retrieved from https://oapub.org/edu/index.php/ejfl/article/view/3245

Redzuan, F. A. P. (2021). A comparative study on motivation in foreign language learning in Brunei and Malaysian universities. Southeast Asia: A Multidisciplinary Journal, 20(1), $16-$ 34. Retrieved from https://fass.ubd.edu.bn/SEA/vol20/SEA-v20-comparative-studymotivation-foreign\%20language.pdf

Sadighi, F., \& Dastpak, M. (2017). The Sources of Foreign Language Speaking Anxiety of Iranian English Language Learners. International Journal of Education and Literacy Studies, 5(4), 111-115. Retrieved from 
https://www.journals.aiac.org.au/index.php/IJELS/article/view/3930

Talal, A. (2021). Online learning during the COVID-19 pandemic from the perspectives of English as foreign language students. Educational Research and Reviews, 16(7), 279288. https://doi.org/10.5897/err2021.4169

Wan Mustapha, W. Z., Ismail, N., Singh, D. S. R., \& Alias, S. E. (2010). ESL students' communication apprehension and their choice of communication activities. ASEAN Journal of Teaching and Learning, 2(1), 22-29. ISSN 1985-5826. Retrieved from http://journalarticle.ukm.my/1493/ 